\title{
Diabetes Insipidus in Severe COVID-19 Pneumonia
}

\author{
Ağır COVID-19 Pnömonisinde Diabetes Insipitus
}

Özge Pekşen', Kezban Özmen Süner², Halil Kızılışık', Havva Kocayiğit ${ }^{3}$, Ali Fuat Erdem ${ }^{1}$

\begin{abstract}
Coronavirus disease 2019 (COVID-19) usually presents as a respiratory infection, and may progress to multiple organ failure and eventually death. In COVID-19 patients, kidney dysfunctions reported proteinuria, elevated markers of blood urea nitrogen, plasma creatinine, uric acids, and D-dimer. We present here the case of a 49 -year-old male who was admitted to the intensive care unit (ICU) with COVID19 pneumonia and respiratory failure. Diabetes insipidus (DI) developed during intensive care follow-up without electrolyte imbalance or kidney failure. A contrast-enhanced brain and pituitary MRI was performed to identify the etiology of the central DI, but revealed no pathological findings. The drugs used to treat our patient had no polyuria side effects. No electrolyte imbalance was identified from a blood test of our patient, and there were no findings of other diseases in the differential diagnosis that could lead to nephrogenic DI. We present here a case of COVID-19 infection complicated by nephrogenic diabetes insipidus, given the lack of reports in literature indicating the occurrence of diabetes insipidus alongside COVID-19 infection.
\end{abstract}

Key words: Diabetus insiputus, COVID-19, severe pneumonia.

\section{Özet}

Coronovirüs 2019 (COVID-19), çoklu organ yetmezliği ve ölümle sonuçlanabilen bir solunum sistemini enfeksiyonudur. COVID-19 hastalarında, proteinüri, yüksek kan üre, plazma kreatinin, ürik asit ve d-dimer seviyeleri böbrek disfonksiyonu olarak bildirilmiştir. Kırk dokuz yaşında erkek hasta, COVID-19 pnömonisi ve solunum yetmezliği tanıları ile yoğun bakıma kabul edildi. Olgunun yoğun bakım takibinde, elektrolit dengesizliği ve böbrek yetmezliği gelişmeksizin diabetus insipitus (DI) tespit edildi. Hastanın santral DI etyolojisi açısından çekilen kontrastlı beyin ve hipofiz MR görüntülemesi normal olarak değerlendirildi. Hastanın aldığı tedavilerde, poliüriye neden olacak ilaç yoktu. Kan testlerinde elektolit dengesizliği tespit edilmedi. Hastada nefrojenik DI' a neden olabilecek başka bir bulgu ve hastalık tespit edilmedi. Bu olgu sunumu, COVID-19 enfeksiyonuna bağlı görülen nefrojenik DI olması açısından litaratürdeki ilk sunumdur. Ağır COVID-19 hastaları ve DI ilişkisinin ortaya konulması için daha çok çalışmaya ihtiyaç vardır.

Anahtar Sözcükler: Diabetes insiputus, COVID-19, ağır pnömoni.
'Department of Anesthesiology and Reanimation, Sakarya University Faculty of Medicine, Sakarya, Turkey

${ }^{2}$ Department of Intensive Care, Sakarya University Education and Research Hospital, Sakarya, Turkey

${ }^{3}$ Department Anesthesiology and Reanimation, Sakarya University Education and Research Hospital, Sakarya, Turkey
'Sakarya Universitesi Tıp Fakültesi, Anesteziyoloji ve Reanimasyon Anabilim Dalı, Sakarya

${ }^{2}$ Sakarya Üniversitesi Eğitim Araşırma Hastanesi, Yoğun Bakım Ünitesi, Sakarya

${ }^{3}$ Sakarya Üniversitesi Eğitim Araşıırma Hastanesi, Anesteziyoloji ve Reanimasyon Anabilim Dalı, Sakarya

Submitted (Başvuru tarihi): 11.05.2021 Accepted (Kabul tarihi): 06.10.2021

Correspondence (iletişim): Kezban Özmen Süner, Department of Intensive Care, Sakarya University Education and Research Hospital, Sakarya, Turkey 
Coronavirus disease 2019 (SARS-CoV-2 - COVID-19), which was declared a pandemic by the World Health Organization in March 2020, usually presents as a respiratory infection that can progress to pneumonia (1). Recent studies suggest that COVID-19 can affect multiple organs, leading to organ failure and possibly death (2). Although SARS-CoV-2 primarily affects the lungs, it can also affect the liver, kidney, heart, stomach, intestine, blood and the immune system, and can lead to multiple organ failure (3). In the presence of COVID-19, preexisting endocrinological and nephrological diseases may be aggravated. In COVID-19 patients, kidney dysfunction can lead to proteinuria, elevated markers of blood urea nitrogen and plasma creatinine (4). Diabetes insipidus (DI) is a syndrome that is characterized by excretions of abnormally large volumes of dilute urine (5).

There remains a lack of data in literature on the potential occurrence of diabetes insipidus in COVID-19 infections. We present here a case of COVID-19 infection complicated by nephrogenic diabetes insipidus.

\section{CASE}

A 49-year-old male was admitted to the emergency room with dyspnea and cough, and with no known additional systemic disease or drug use. Thorax CT revealed a diffuse ground-glass appearance, consistent with COVID-19 pneumonia, and a subsequent COVID-19 polymerase chain reaction (PCR) test was positive. The patient was admitted to the intensive care unit (ICU) with low oxygen saturation and dyspnea, and prescribed nasal oxygen, favipiravir, hydroxychloroquine, moxifloxacin, dexamethasone and low molecular-weight heparin treatment. Upon admission, the patient's blood test results were $\mathrm{Hb}$ : $12.7 \mathrm{~g} / \mathrm{dl}, \mathrm{WBC}: 8.3 \times 109 / \mathrm{mL}$, platelets: $413 \times 109 / \mathrm{mL}$, urea: $24 \mathrm{mg} / \mathrm{dL}$, creatinine: $0.6 \mathrm{mg} / \mathrm{dL}, \mathrm{Na}: 136 \mathrm{mmol} / \mathrm{L}$, $\mathrm{K}: 3.8 \mathrm{mmol} / \mathrm{L}, \mathrm{Ca}: 8.6 \mathrm{mg} / \mathrm{Dl}$, D-dimer: $818 \mu \mathrm{gFEU} / \mathrm{L}$, ferritin: $1673.68 \mu \mathrm{g} / \mathrm{L}$ and CRP: $262 \mathrm{mg} / \mathrm{L}$ (Table 1). Noninvasive ventilation (NIV) support was given to the patient due to respiratory failure, but despite this, the patient, whose respiratory rate was $>30$ and $\mathrm{PO}_{2} / \mathrm{FiO}_{2}$ was $<100$, was intubated on the third day in the ICU. Additionally, sedoanalgesics (midazolam, fentanyl, propofol), norepinephrine and dopamine infusion were added to the treatment protocol.

The patient's polyuria started on the fifth day in ICU, when urine output increased to over seven liters in 24 hours. On the same day, urine density was 1010, urine osmolality was $433 \mathrm{mOsm} / \mathrm{kgH}_{2} \mathrm{O}$, serum osmolarity was
$295 \mathrm{mOsm}$, and urine was protein negative when the patient's polyuria started, with no electrolyte imbalance (Table 2). The patient was started on fluid replacement therapy, but the polyuria continued. Intranasal desmopressin spray was added to the treatment. However, there was no significant reduction in the amount of urine output and no change in urine $\mathrm{Na}$, urine osmolality or specific gravity. On the day the polyuria started, the laboratory values were $\mathrm{Hb}: 11.4 \mathrm{~g} / \mathrm{dl}, \mathrm{WBC}: 11.6 \times 109 / \mathrm{mL}$, platelets: $464 \times 109 / \mathrm{mL}$, urea: $119 \mathrm{mg} / \mathrm{dL}$, creatinine: 1.08 $\mathrm{mg} / \mathrm{dL}, \mathrm{Na}: 145 \mathrm{mmol} / \mathrm{dL}, \quad \mathrm{K}: 5.1 \mathrm{mmol} / \mathrm{dL}, \quad \mathrm{Ca}:$ $8.9 \mathrm{mg} / \mathrm{dL}$, urine density: 1007, urine osmolality: $230 \mathrm{mOsm} / \mathrm{kgH}_{2} \mathrm{O}$, serum osmolality: $268 \mathrm{mOsm}$ and urine protein negative (Table2).

A contrast-enhanced brain and pituitary MRI was performed for the etiology of polyuria, revealing no pathological finding, and so nephrogenic diabetes insipidus was considered. A Schirmer test performed for the differential diagnosis of Sjogren provided a negative result. On follow-up, urine output had decreased but the polyuria persisted. In this polyuria phase, the patient's fluid replacement and urine output were followed, and no electrolyte imbalance was noted during this period.

The patient was extubated on the 20th day of admission to the ICU after his respiratory parameters improved, and after the need for intensive care subsided, he was transferred to the nephrology service on the 28th day following admission. He was discharged with recovery on the seventh day of nephrology service follow-up.

\section{DISCUSSION}

In December 2019, Wuhan, China experienced a severe coronavirus outbreak (SARS-CoV-2) - a severe acute respiratory syndrome - named subsequently COVID-19 (6). The symptoms of COVID-19 are similar to those of other respiratory viruses, including fever, cough, fatigue, diarrhea, vomiting and dyspnea. Patients with severe COVID-19 may develop acute respiratory distress syndrome or shock (7). COVID-19 can also affect various organs and systems, such as the lung, liver, kidney and heart, and the gastrointestinal, hematological and nervous systems, with a high rate of mortality (8). Acute kidney injury may develop in COVID-19 patients (4-7). According to data on hospitalized COVID-19 patients, the incidence of acute kidney injury (AKI) is $29 \%$ among severe cases, and reaches $69.57 \%$ in those aged $\geqslant 60$ (9). 
Table 1: Laboratory findings of the patient on admission to ICU and while intranasal desmopressin treatment

\begin{tabular}{|c|c|c|}
\hline & On Admission & $\begin{array}{c}\text { On the day } \\
\text { polyria started }\end{array}$ \\
\hline Hemoglobin, $\mathrm{g} / \mathrm{dL}$ & 12.7 & 11.4 \\
\hline Platelets, $\mathbf{x} 109 / \mathrm{mL}$ & 8.3 & 11.6 \\
\hline Urea, $\mathrm{mg} / \mathrm{dL}$ & 413 & 464 \\
\hline Creatinine, $\mathrm{mg} / \mathrm{dL}$ & 24 & 119 \\
\hline Sodium, $\mathrm{mmol} / \mathrm{L}$ & 0.6 & 1.08 \\
\hline Potassium, $\mathrm{mmol} / \mathrm{L}$ & 136 & 145 \\
\hline D-dimer, ugFEU/L & 3.8 & 5.1 \\
\hline Ferritin, $\mu \mathrm{g} / \mathrm{L}$ & 818 & \\
\hline C-reactive $\mathrm{protein}, \mathrm{mg} / \mathrm{L}$ & 1673 & \\
\hline
\end{tabular}

Table 2: Laboratory findings of the patient on the day polyria started and after intranasal desmopressin treatment

\begin{tabular}{|c|c|c|}
\hline Urine density & On Admission & $\begin{array}{c}\text { On the day } \\
\text { polyria started }\end{array}$ \\
\hline $\begin{array}{c}\text { Urineosmolatity, } \\
\mathrm{mOsm} / \mathrm{kgH}_{2} \mathrm{O}\end{array}$ & 1010 & 1007 \\
\hline Serum osmolarity, m0sm & 295 & 230 \\
\hline Urine protein & negative & negative \\
\hline
\end{tabular}

There is currently no data related to diabetes insipidus in COVID-19 patients. In our case, diabetes insipidus developed during intensive care follow-up, but without electrolyte imbalance or kidney failure. Diabetes insipidus (DI) is a form of polyuria-polydipsia syndrome that is characterized by hypotonic polyuria (excessive urination; $>50$ $\mathrm{ml} / \mathrm{kg}$ body weight $/ 24 \mathrm{~h}$ ) and polydipsia (excessive drinking of $>3 \mathrm{~L} /$ day) (10). It can be of the central or nephrogenic type.

In COVID-19 patients, stroke, encephalopathy, seizures and cranial nerve deficits (e.g., neurological complications) can be seen. We originally considered central DI, but the patient's urine osmolality was low and did not change after the administration of vasopressin. There was no pathological finding in a brain and pituitary MRI, and so nephrogenic DI was considered. There is only one previous study in literature reporting on central DI in a COVID-19 patient, in which it was reported that a brain MRI showed no acute infarction, intracranial hemorrhage or mass, and no abnormal intracranial enhancement (11). Renal resistance to the antidiuretic effect of vasopressin is commonly referred to as nephrogenic diabetes insipidus. In nephrogenic $\mathrm{DI}$, renal tubular abnormalities can be acquired (drugs, electrolytes, obstruction, vascular granuloma, sarcoid sarcoma or amyloid), genetic or idiopathic (12). The drugs used for the treatment of our patient have no known polyuria side effects; no electrolyte imbalance was observed in blood tests; and there were no findings of other diseases in a differential diagnosis that could cause nephrogenic DI. Notably, there is a lack of information in literature reporting the occurrence of diabetes insipidus related to COVID-19 infection.

Our patient developed severe acute respiratory syndrome and multiple organ failure (MOF) due to the COVID-19 infection. Given the lack of available data, the mechanisms of diabetes insipidus in COVID-19 are not yet clearly defined. Severe ARDS and MOF due to COVID19 infection can cause nephrogenic diabetes insipidus through the more specific mechanisms of autoimmune dysregulation, leading to autonomic and neuroendocrine derangements. Previous studies have shown the involvement of the hypothalamic-pituitary axis in COVID-19 $(13,14)$. Inflammation-related reversible hypophysitis and direct autoimmune damage could be possible explanations for the damage to the hypothalamic-pituitary axis. Another hypothesis suggests that a high expression of ACE-2 receptors can damage hypothalamic and pituitary tissues, and this involvement of the hypothalamic-pituitary axis may cause DI.

\section{CONCLUSION}

In presenting this case, we wanted to draw attention to the possible association of diabetes insipidus in patients followed up in intensive care units due to COVID-19 pneumonia. Further studies of this complex viral infection will answer these questions.

\section{CONFLICTS OF INTEREST}

None declared.

\section{AUTHOR CONTRIBUTIONS}

Concept - Ö.P., K.Ö.S., H.Kı., H.Ko., A.F.E.; Planning and Design - Ö.P., K.Ö.S., H.Kı., H.Ko., A.F.E.; Supervision - Ö.P., K.Ö.S., H.Kı., H.Ko., A.F.E.; Funding -; Materials -; Data Collection and/or Processing - H.Kı.; Analysis and/or Interpretation - H.Ko.; Literature Review K.Ö.S.; Writing - Ö.P.; Critical Review - A.F.E.

\section{YAZAR KATKILARI}

Fikir - Ö.P., K.Ö.S., H.Kı., H.Ko., A.F.E.; Tasarım ve Dizayn - Ö.P., K.Ö.S., H.Kı., H.Ko., A.F.E.; Denetleme Ö.P., K.Ö.S., H.Kı., H.Ko., A.F.E.; Kaynaklar -; Malze- 
meler -; Veri Toplama ve/veya İşleme - H.Kı.; Analiz ve/veya Yorum - H.Ko.; Literatür Taraması - K.Ö.S.; Yazıyı Yazan - Ö.P.; Eleştirel İnceleme - A.F.E.

\section{REFERENCES}

1. Harapan H, Itoh N, Yufika A, Winardi W, Keam S, Te H, et al. Coronavirus disease 2019 (COVID-19): A literatüre review. J Infect Public Health 2020; 13:667-73. [CrossRef]

2. Li $Q$, Guan X, Wu P, et al. Early transmission dynamics in Wuhan, China, of novel coronavirus-infected pneumonia. N Engl J Med 2020; 382:1 199-207. [CrossRef]

3. Wang T, Du Z, Zhu F, Cao Z, An Y, Gao Y, et al. Comorbidities and multi-organ injuries in the treatment of COVID-19. Lancet 2020; 395:e52. [CrossRef]

4. Li Z, Wu M, Yao J, Guo J, Liao X, Song S, et al. Caution on Kidney Dysfunctions of COVID-19 Patients. medRxiv 2020.02.08.20021212. [CrossRef]

5. Robertson GL. Diabetes insipidus. Endocrinol Metab Clin North Am 1995; 24:549-572. [CrossRef]

6. Zhou F, Yu T, Du R, Fan G, Liu Y, Liu Z, et al. Clinical course and risk factors for mortality of adult in patients with COVID-19 in Wuhan, China: a retrospective cohort study. Lancet 2020; 395:1054-62. [CrossRef]

7. Zhang X, Cai H, Hu J, Lian J, Gu J, Zhang S, et al. Epidemiological, clinical characteristics of cases of SARS-
CoV-2 infection with abnormal imaging findings. Int J Infect Dis 2020; 94:81-7. [CrossRef]

8. Gupta A, Madhavan MV, Sehgal K, Nair N, Mahajan S, Sehrawat TS, et al. Extrapulmonary manifestations of COVID-19. Nat Med 2020; 26:1017-32. [CrossRef]

9. Diao B, Wang C, Wang R, Feng Z, Zhang J, Yang H, et al. Human kidney is a target for novel severe acute respiratory syndrome coronavirus 2 (SARS-CoV-2) infection. NATURE COM 2021; 12: 2506. [CrossRef]

10. Christ-Crain M, Bichet DG, Fenske WK, Goldman MB, Rettig $S$, Verbalis JG, et al. Diabetes insipidus. Nat Rev Dis Primers 2019; 5:54. [CrossRef]

11. Rajevac H, Bachan M, Khan Z. Diabetes insipidus as a symptom of covid-19 infection: case report. Chest 2020; 158:A2576. [CrossRef]

12. Robertson GL. Diabetes insipidus: Differential diagnosis and management. Best Prac Res Clin Endocrinol Metab 2016; 30:205-18. [CrossRef]

13. Leow MKS, Kwek DSK, Ng AWK, Ong KC, Kaw GJL, Lee LSU. Hypocortisolism in survivors of severe acute respiratory syndrome (SARS). Clin Endocrinol (Oxf) 2005; 63:197-202. [CrossRef]

14. Lazartigues E, Qadir MMF, Mauvais-Jarvis F. Endocrine significance of SARS-CoV-2's reliance on ACE2. Endocrinology 2020; 161:bqaa108. [CrossRef] 